Jurnal Care Vol. 4, No.3, Tahun 2016

\title{
HUBUNGAN AKTIVITAS MENONTON TELEVISI DENGAN STATUS GIZI PADA ANAK USIA SEKOLAH 6-8 TAHUN DI SDN MERJOSARI 02 MALANG
}

\author{
Theresia Fieny ${ }^{1}$, Joko Wiyono ${ }^{2}$ Yanti Rosdiana ${ }^{3}$ \\ ${ }^{1,3)}$ Program Studi Ilmu Keperawatan Universitas Tribhuwana Tunggadewi \\ ${ }^{2}$ Poltekes Malang \\ e-mail: yun_tea8@yahoo.co.id
}

\begin{abstract}
Watching television activity is one important factor that indicate the person's nutritional status. Excessive intake of nutrients which is not balanced with energy expenditure will lead to obesity. The purpose of this study was to determine the relationship between watching television activity with the nutritional status of school age $6 \sim 8$ years children in Merjosari 02 Public Elementary School of Malang. This study was an observational study with cross sectional approach. The population is all children of school age 6 8 years as many as 20 people with a saturated sampling technique. The instrument was questionnaire. Analysis data using Spearman Rank statistical test, significance level $(0,05)$. The research results revealed the majority of respondents have a television event on Sunday in the long time category of 15 people (75\%), Monday 11 people (55\%), on Tuesday 13 people (65\%), and most of the respondents nutritional status in the obese category namely male 6 (30\%) and 7 women (37\%). Statistical test p value $=0,22$ means p value> 0,05. This means that there was no relationship between the watching television activity with the school age $6 \sim 8$ years children nutritional status. Recommended to conduct further research by enlarging the research samples and inclose the determinant factor.
\end{abstract}

Keywords: watched television activity, nutrient status, school age children

\section{ABSTRAK}

Aktivitas menonton televisi merupakan salah satu faktor penting yang menentukan status gizi seseorang.Asupan nutriri yang berlebih tidak diimbangi dengan pengeluaran energi akan menyebabkan terjadinya kegemukan. Tujuan dari penelitian ini adalah untuk mengetahui antara hubungan aktivitas menonton televisi dengan status gizi pada anak usia sekolah 6-8 tahun di SDN Merjosari 02 Malang. Penelitian ini merupakan penelitian observasional dengan pendekatan cross sectional. Populasinya adalah semua anak usia sekolah 6-8 tahun sebanyak 20 orang dengan teknik sampling sampel jenuh. Instrumen yang digunakan adalah lembar kuesioner.Analisa data dengan menggunakan uji statistik spearman rank, derajat kemaknaan $(0,05)$.Hasil penelitian diketahui sebagian besar responden mempunyai aktivitas menonton 
Jurnal Care Vol. 4, No.3, Tahun 2016

televisi di Hari Minggu dalam kategori lama sebanyak 15 orang (75\%), Senin 11 orang (55\%), Selasa 13 orang $(65 \%)$, dan sebagian besar status gizi responden dalam kategori gemuk yakni laki-laki 6 orang $(30 \%)$ dan perempuan 7 orang $(37 \%)$. Uji statistik p-value $=0,22$ $\mathrm{p}$-value $>0,05$. Artinya tidak ada hubungan antara aktivitas menonton televisi dengan status gizi pada anak usia sekolah 6-8 tahun.Direkomendasikan untuk melakukan penelitian lanjutan dengan memperbesar sampel penelitian dan menyertakan faktor determinannya.

Kata kunci : Aktivitas menonton televisi, Status gizi,anak sekolah

\section{PENDAHULUAN}

Anak merupakan individu yang berada dalam satu rentangan perubahan perkembangan yang dimulai dari bayi hingga remaja. Masa anak merupakan masa pertumbuhan dan perkembangan yang dimulai dari usia bayi(0-1 tahun), usia bermain/toddler ( 3-5 tahun), prasekolah (3-6 tahun), usia sekolah (6-12 tahun), hingga remaja (12-18 tahun). Anak memiliki suatu ciri yang khas yaitu selalu tumbuh dan berkembang secara teratur, saling berkaitan, dan berkesinambungan dimulai sejak konsepsi sampai dewasa. Karakteristik tumbuh kembang spesifik terhadap usia anak (Duma, 2013).

Pemberian nutrisi untuk anak dengan kualitas dan kuantitas yang baik akan berdampak pada tumbuh kembang anak yang baik pula. Dalam masa tumbuh kembang tersebut pemberian nutrisi atau asupan makanan pada anak tidak selalu dapat dilaksanakan dengan sempurna. Sering timbul masalah terutama dalam pemberian makanan yang tidak benar dan menyimpang. Penyimpangan ini berakibat gangguan pada banyak organ-organ dan system tubuh anak (Depkes, 2005).Jika penyimpangan pemberian makan tersebut terjadi dalam jangka waktu yang lama, maka berakibat pada kesehatan anak yang buruk.

Televisi merupakan bentuk media massa yang paling berpengaruh dalam konsumsi anak dan sebagai media mengisi waktu luang yang paling popular bagi anak (Triwardani, 2007). Data WHO menyatakan bahwa salah satu faktor penyebab peningkatan kejadian overweight dan obesitas anak adalah meningkatnya perilaku sedentary dan berkurangnya aktivitas fisik. Perilaku sedentary misalnya seperti menonton TV, penggunaan komputer, bermain video game.Penelitian Suprihatun juga menunjukkan aktivitas fisik 
Jurnal Care Vol. 4, No.3, Tahun 2016

rendah, meliputi banyaknya aktivitas bermain didalam rumah, kurang aktivitas bermain diluar rumah, dan banyak menonton TV/bermain game di komputer berisiko terhadap kejadian obesitas pada anak.

Konsumsi makan dan kurangnya aktivitas fisik menjadi faktor penting terjadinya obesitas. Anak-anak pada masa sekarang sangat terpaku pada televisi yang dimana mereka dapat menghabiskan waktu selama 24 jam per minggu untuk menonton tayangan di televisi. Banyak juga anak-anak menghabiskan waktu sekitar 10 jam per minggu untuk bermain komputer dan video games. Penelitian di Amerika pada anakanak menunjukkan bahwa anak dengan lama waktu menonton televisi 5 jam per hari, memiliki resiko obesitas sebesar 5.3 kali lebih besar daripada anak dengan lama menonton 2 jam per hari (Triwardani, 2007). Dalam sebuah penelitian yang dilaporkan jurnal pediatrics, terbitan Amerika Serikat mengemukakan adanya hubungan kebiasaan aktivitas menonton televisi dengan kecenderungan obesitas pada anak dan remaja. Dari penelitian ini menyebutkan bahwa tiap alokasi waktu untuk menonton televisi 1 jam akan meningkat kemungkinan terjadinya obesitas sebesar 2\%. Hal ini mereka simpulkan dengan mempelajari kesehatan dan kebiasaan anak menonton televisi pada 1500 anak Amerika. Perilaku bermalasmalasan atau kurangnya aktivitas fisik menjadi salah satu penyebab kegemukan pada anak sekolah (Triwardani, 2007).Berdasarkan data tersebut maka The American Academi of pedriatrics merekomendasikan batasan untuk menonton televisi dan video games untuk anak-anak yaitu sekitar 14 jam per minggu (Triwardani, 2007).

Aktivitas merupakan gerakan tubuh yang dihasilkan oleh otot rangka yang memerlukan pengeluaran energi. Aktivitas fisik yang kurang menjadi salah satu faktor risiko langsung untuk penyakit kronis seperti obesitas, dan penyakit ini secara keseluruhan diperkirakan menyebabkan kematian secara global (WHO, 2010). Seorang anak yang banyak menghabiskan waktu dengan kegiatan yang tidak mengeluarkan keringat, seperti menonton televisi atau bermain video games, maka dianjurkan untuk lebih banyak melakukan aktivitas fisik. Pemerintah dan ahli kesehatan di Amerika merekomendasikan 
Jurnal Care Vol. 4, No.3, Tahun 2016

untuk melakukan aktivitas fisik selama 60 menit atau lebih supaya membantu anak mencapai berat badan ideal dan dapat menjaga berat badannya di kemudian hari (Triwardani, 2007).

Tubuh memerlukan energi untuk fungsifungsi organ tubuh, pergerakan tubuh, mempertahankan suhu, fungsi enzim, pertumbuhan dan pergantian sel yang rusak. Metabolisme merupakan semua proses biokimia pada sel tubuh. Proses metabolisme dapat berupa anabolisme (membangun) dan katabolisme (pemecah). Masalah nutrisi erat kaitannya dengan asupan makanan, metabolisme tubuh serta faktor-faktor yang mempengaruhinya. Secara umum faktor yang mempengaruhi kebutuhan nutrisi adalah faktor fisiologis untuk kebutuhan metabolisme basal, faktor patologis seperti adanya penyakit tertentu yang menganggu pencernaan atau meningkatkan kebutuhn nutrisi, faktor sosio-ekonomi seperti adanya kemampuan individu dalam memenuhi kebutuhan nutrisi (Supariasa et al, 2001). Konsumsi makan berlebih pada anak, yang tidak disertai dengan aktivitas fisik akan berdampak pada status gizi anak yang lebih.
Status gizi merupakan suatu keadaan tubuh yang diakibatkan oleh keseimbangan antara asupan zat gizi dengan kebutuhan. Keseimbangan tersebut dapat dilihat dari variabel pertumbuhan, yaitu berat badan, tinggi badan/panjang badan, lingkar kepala, lingkar lengan, dan panjang tungkai (Khomsan, 2000). Masalah gizi saat ini telah menjadi perhatian global. Sebagian besar negara-negara maju dan berkembang mengalami peningkatan masalah gizi lebih dan obesitas (Khan, 2006; WHO, 2007). Masalah gizi yang berkembang di masyarakat sangat erat hubungannya dengan perilaku dan gaya hidup pada masa kanak-kanak dan remaja (Duma, 2013). Sekitar 80\% obesitas pada masa kanakkanak dan remaja akan terus berkembang menjadi obesitas pada saat dewasa dan semakin sulit untuk diubah (Tendean, 2011).

Berdasarkan data RISKESDAS (2010) masalah kegemukan pada anak sekolah berusia 6-12 tahun masih tinggi yaitu $9,2 \%$ atau masih di atas 5,0\%. Prevalensi kegemukan pada anak laki-laki umur 6-12 tahun lebih tinggi dari prevalensi pada anak perempuan yaitu berturut-turut sebesar $10,7 \%$ dan $7,7 \%$. 
Jurnal Care Vol. 4, No.3, Tahun 2016

Prevalensi kegemukan lebih tinggi di perkotaan dibandingkan dengan di perdesaan yaitu yakni 10,4\% dan 8,1\%. Berdasarkan uraian diatas maka peneliti sangat tertarik untuk melakukan penelitian tentang hubungan aktivitas menonton televisi dengan status gizi aak usia sekolah 6-8 tahun.

\section{METODE PENELITIAN}

Desain penelitian yang digunakan oleh peneliti adalah desain kolerasional yang bertujuan mencari, menjelaskan hubungan, memperkirakan, dan menguji berdasarkan teori yang ada antara variabel (Nursalam, 2013). Pendekatan yang dipakai dalam proses penelitian ini adalah cross sectional yaitu penelitian pada beberapa populasi yang diamati pada waktu yang sama. (Alimul. A, 2009). Variabel bebas dalam penelitian ini adalah aktivitas menonton televisi, sedangkan variabel terikat adalah status gizi. Intrumen yang digunakan dalam penelitian ini adalah lembar kuesioner.
Data aktivitas menonton televisi dapat dilihat dari hasil pengisian pertanyaan terbuka yang telah tersedia dilembar kuesioner mengenai durasi atau lama menonton televisi yang dilakukan anak dalam satu hari. Nilai diperoleh dari lamanya waktu yang digunakan untuk menonton televisi dalam jam. Kemudian nilai tersebut dikategorikan untuk selanjutnya dianalisis bivariat. Lamanya aktivitas menonton televisi, dikategorikan sebagai berikut :

1. Lama : $3-5$ jam

2. Sedang : $2-3$ jam

3. Kadang-kadang: 1 jam

Data status gizi dilihat dari hasil penimbangan berat badan dan hasil pengukuran tinggi badan. Lalu dihitung dengan menggunakan rumus Indeks Masa Tubuh. Kemudian disesuaikan dengan tabel kategori ambang batas IMT utuk Indonesia. Ambang batas IMT dapat dilihat pada Tabel 1 di bawah ini

Tabel 1. Ambang Batas IMT untuk Indonesia

\begin{tabular}{cllllll}
\hline \multirow{2}{*}{$\begin{array}{l}\text { Umur } \\
\text { (thn) }\end{array}$} & \multicolumn{3}{c}{ Laki-laki } & \multicolumn{3}{c}{ Perempuan } \\
\cline { 2 - 6 } & Kurus & Normal & Gemuk & Kurus & Normal & Gemuk \\
\hline 6 & $<13,0$ & $13,0-18,4$ & $>18,5$ & $<12,7$ & $12,8-19,1$ & $>19,2$ \\
7 & $<13,2$ & $13,3-18,9$ & $>19,0$ & $<12,7$ & $12,8-19,2$ & $>19,8$ \\
8 & $<13,3$ & $13,4-19,6$ & $>19,7$ & $<12,9$ & $13,0-20,7$ & $>20,8$ \\
\multicolumn{2}{c}{ Sumber : WHO (2007) } & & & & & \\
\hline
\end{tabular}


Jurnal Care Vol. 4, No.3, Tahun 2016

\section{HASIL}

Hasil penelitian terkait usia anak di SDN Merjosari 02 Malang didapatkan bahwa hampir setengahnya dari responden berusia 8 tahun yakni sebanyak 9 orang (45\%); sebanyak 5 orang $(25 \%)$ berusia 6 tahun; dan sebanyak 6 orang $(30 \%)$ berusia 7 tahun.

Berdasarkan jenis kelamin anak diketahui bahwa sebagian besar anak usia sekolah berjenis kelamin perempuan yakni sebanyak 11 orang (55\%) dan laki-laki sebanyak 9 orang $(45 \%)$.

Berdasarkan kelas anak diketahui sebagian besar anak kelas dua yakni sebanyak 12 orang $(60 \%)$; dan sebanyak 8 orang $(40 \%)$ kelas satu.

Tabel 2. Distribusi Frekuensi Berdasarkan Durasi Anak Menonton Televisi pada Hari Minggu di SDN Merjosari 02 Malang

\begin{tabular}{lcc}
\hline Durasi (jam) & Jumlah & $(\%)$ \\
\hline Lama(3-5 ) & 15 & 75 \\
Sedang(2-3) & 5 & 25 \\
Kadang-kadang (1) & 0 & 0 \\
\hline \multicolumn{1}{c}{ Total } & 20 & 100 \\
\hline
\end{tabular}

Berdasarkan Tabel 2 dapat diketahui bahwa sebagian besar anak menonton televisi dengan durasi lama (3-5 jam) pada hari Minggu yakni sebanyak 15 orang (54\%).

Tabel 3. Distribusi Frekuensi Berdasarkan Durasi Anak Menonton Televisi pada Hari Senin di SDN Merjosari 02 Malang

\begin{tabular}{lcc}
\hline Durasi (jam) & Jumlah & $(\%)$ \\
\hline Lama (3-5) & 11 & 55 \\
Sedang (2-3) & 7 & 35 \\
Kadang-kadang (1) & 2 & 10 \\
\hline \multicolumn{1}{c}{ Total } & 20 & 100 \\
\hline
\end{tabular}

Berdasarkan Tabel 3 dapat diketahui bahwa sebagian besar anak menonton televisi dengan durasi lama (3-5 jam) pada hari Senin yakni sebanyak 11 orang (55\%).

Tabel 4. Distribusi Frekuensi Berdasarkan Durasi Anak Menonton Televisi pada Hari Selasa di SDN Merjosari 02 Malang

\begin{tabular}{lcc}
\hline Durasi (jam) & Jumlah & $(\%)$ \\
\hline Lama (3-5 jam) & 13 & 65 \\
Sedang (2-3 jam) & 7 & 35 \\
Kadang-kadang (1 jam $)$ & 0 & 0 \\
\hline \multicolumn{1}{c}{ Total } & 20 & 100 \\
\hline
\end{tabular}

Berdasarkan Tabel 4 di bawah dapat diketahui bahwa sebagian besar anak menonton televisi dengan durasi lama (3-5 jam) pada hari Selasa yakni sebanyak 13 orang $(65 \%)$. 
Jurnal Care Vol. 4, No.3, Tahun 2016

Tabel 5. Status Gizi Anak di Sekolah Dasar

Negeri(SDN) Merjosari 02

Malang

\begin{tabular}{lcccc}
\hline \multirow{2}{*}{ IMT } & \multicolumn{2}{l}{ Frekuensi } & \multicolumn{2}{c}{$(\%)$} \\
\cline { 2 - 5 } & $\mathrm{L}$ & $\mathrm{P}$ & $\mathrm{L}$ & $\mathrm{P}$ \\
\hline Gemuk & 6 & 7 & 30 & 35 \\
Normal & 3 & 3 & 15 & 15 \\
Kurus & 0 & 1 & 0 & 5 \\
\hline \multicolumn{1}{c}{ Total } & 20 & & \multicolumn{2}{c}{100} \\
\hline
\end{tabular}

Berdasarkan Tabel 5 diketahui bahwa sebanyak 6 anak laki-laki(30\%) dan 7 anak perempuan $(35 \%)$ mempunyai status gizi gemuk.

Hasil uji statistik dengan menggunakan spearman rank dengan derajat kemaknaan $(0,05)$ didapatkan pvalue $=0,22$. Artinya tidak ada hubungan antara aktivitas menonton televisi dengan status gizi pada anak usia sekolah 6-8 tahun di SDN Merjosari 02 Malang

\section{PEMBAHASAN}

Aktivitas fisik adalah gerakan tubuh yang dihasilkan oleh otot-otot rangka yang dihasilakn sebagai suatau pengeluaran tenaga (dinyatakan kilo-kalori), yang meliputi pekerjaan, waktu senggang dan aktivitas sehari-hari. Aktivitas tersebut memerlukan usaha ringan, sedang atau berat yang dapat menyebabkan perbaikan kesehatan bila dilakukan secara teratur (Duma, 2013).

Berdasarkan umur, hampir setengah responden berusia 8 tahun yakni sebanyak 9 orang (45\%). Pada usia 8 tahun anak sering melakukan aktivitas. Tinggi rendahnya seorang anak melakukan aktifitas dipengaruhi oleh banyak faktor dan salah satunya adalah pengeluaran energi (Burtom, 2007). Usia anak 8 tahun seharusnya melakukan aktivitas fisik sekitar 60 menit. Aktifitas seorang anak akan meningkat sampai mencapai usia 25-30 tahun, kemudian akan mengalami penurunan aktifitas dengan sendirinya. Semakin bertambahnya usia anak maka semakin menurun aktifitas anak tersebut (Burtom,2007).

Karakteristik lamanya menonton telavisi pada anak pada hari minggu 15 jam (75\%), pada hari senin 11 jam (55\%) dan pada hari selasa 13 jam (65\%). Menonton televisi merupakan kegiatan yang sedikit mengeluarkan aktivitas anak. Lama waktu anak menonton tv dalam 5 jam perhari memiliki resiko obesitas sebesar 5-3 kali lebih besar dari pada anak dengan lama menonton 2 jam perhari (Tandean, 2011). 
Jurnal Care Vol. 4, No.3, Tahun 2016

Dari hasil penelitian didapatkan status gizi anak laki-laki dan perempuan dalam kategori gemuk. Dimana sebanyak 7 anak perempuan dan 6 anak laki-laki. Baik tidaknya status gizi pada anak laki-laki ataupun perempuan sangat dipengaruhi oleh faktor pendukung status gizi. Asupan nutrisi sangat mempengaruhi status gizi, jika pengeluaran energi kurang dan asupan nutrisi berlebih maka kemungkinan dapat terjadinya obesitas (Duma, 2013),

Berdasarkan hasil analisa data dengan menggunakan uji korelasi spearman rank didapatkan bahwa tidak ada hubungan yang signifikan antara hubungan aktivitas menonton televisi dengan status gizi pada anak sekolah 6.8 tahun dengan keeratan nilai $p$ value $=0,22$ sehingga dapat disimpulkan $p$ value $0,22>\alpha(0,05)$. Menurut pendapat peneliti dimungkinkan bukan aktivitas menonton televisi yang menyebabkan obesitas tetapi dikarenakan asupan nutrisi yang masuk dalam tubuh seperti mengemil dan ditambah lagi pengeluaran energi kurang. Aktivitas anak menonton televisi tidak selalu diiringi dengan konsumsi makanan jajanan. Adanya faktor genetik,kurangnya aktivitas fisik pada anak serta konsumsi makanan berlebih melebihi kebutuhannya menjadi penyebab terjadinya obesitas pada anak.

\section{KESIMPULAN}

Tidak ada hubungan antara aktivitas menonton televisi dengan status gizi pada anak usia sekolah 6-8 tahun di SDN Merjosari 02 Malang .

Direkomendasikan pada peneliti selanjutnya untuk melakukan penelitian lanjutan dengan memperbesar sampel penelitian dan menyertakan faktor determinannya.

\section{DAFTAR PUSTAKA}

Alimun, A. (2009). Metode Penelitian Keperawatan dan Teknik Analisa Data. Jakarta: Salemba Medika.

Butron, G. (2007). Sebuah Pengantar kepada studi televisi. Yogyakarta: Jalasutra.

Depkes RI. (2005). Pedoman Perbaikan Giz̨i Anak Sekolah Dasar dan Madrasah Ibitidaiyah. Direktoral Jenderal Bina Kesehatan Masyarakat Direktorat Gizi Masyarakat. Jakarta. 
Jurnal Care Vol. 4, No.3, Tahun 2016

Duma, G. (2013). Hubungan Pola makan dan Aktifitas fisik dan kejadian Obesitas Anak. Kelas V dan VI di Sekolah Dasar Yayasan Pendidikan Syafiyatul Amaliyyah. Universitas Sumatera Utara.

Khomsan, A. (2000). Teknik Pengukuran Pengetahuan Gizi. Bogor : Institut Pertanian Bogor.

Nursalam. (2013). Metode Penelitian Ilmu Keperawatan Pendekatan Parktis Edisi3. Jakarta: Salemba Mendika.

Supariasa, et al. (2001). Penelitian Status Gizi. Jakarta: EGC.

Tendean, A. (2011). Hubungan Aktivitas Fisik dengan Status Giri pada Mahasiswa Fakultas Kesehatan Masyarakat Semseter I
Universitas Sam Ratulangi. Manado: Universitas Sam Ratulangi.

Triwardani, R (2007). Kajian Kritis Praktik Anak Menonton Film Kartun di Televisi. Yoyakarta: Universitas GadjahMada.

WHO. (2007). Growth Referece 6-12 year. Diperoleh dari www.who.int.pdf, pada tanggal 20 Mei 2014.

WHO. (2010). Global Recommendations on Physical Activity for Healt. Diperoleh dari http://www.who.com, pada tanggal 26 Mei 2014. 